\title{
Continuous Spinal Anesthesia with High Dose of Local Anesthetics
}

\author{
Luiz Eduardo Imbelloni, TSA 1, Savino Gasparini Neto 2, Eliana Marisa Ganem ${ }^{3}$
}

\begin{abstract}
Summary: Imbelloni LE, Gasparini Neto S, Ganem EM - Continuous Spinal Anesthesia with High Dose of Local Anesthetics.
Background and objectives: Better control of the level, intensity, and duration of spinal analgesia represents the greatest advantages of continuous spinal anesthesia. With the advent of intermediate catheters (over-the-needle catheter) and its low incidence of headaches and neurological symptoms, the technique has been gaining credibility. The objective of this paper is to report the possible safety of the new catheter with a large dose of hyperbaric $0.5 \%$ bupivacaine with $1.6 \%$ glucose associated with hyperbaric $2 \%$ lidocaine with $1.6 \%$ glucose.
\end{abstract}

Case Report: Male patient, 78 years old, $85 \mathrm{~kg}, 168 \mathrm{~cm}$, physical status ASA III, with hypertension, coronary artery disease, and chronic renal failure. The patient was candidate for surgery for huge bilateral inguinal and umbilical hernias, being submitted to preoperative pneumoperitoneum for one week to stretch abdominal cavity. After venoclysis with an $18 \mathrm{G}$ catheter, he was monitored with cardioscope, non-invasive blood pressure, and pulse oximetry; he was sedated with $1 \mathrm{mg}$ of midazolam and $100 \mu \mathrm{g}$ of fentanyl intravenously, and placed in left lateral decubitus. He underwent continuous spinal anesthesia by a median puncture in $\mathrm{L}_{3}-\mathrm{L}_{4}$ with a set with a $27 \mathrm{G}$ cut-bevel needle and $22 \mathrm{G}$ catheter. The total dose of anesthetic used was $25 \mathrm{mg}$ of $0.5 \%$ bupivacaine (hyperbaric, with $1.6 \%$ glucose), $160 \mathrm{mg}$ of $2 \%$ lidocaine (hyperbaric, with $1.6 \%$ glucose), and morphine $(100 \mu \mathrm{g})$. The patient was followed-up until the $30^{\text {th }}$ postoperative day without neurological complaints.

Conclusions: Recently, the poor distribution of the local anesthetic through the microcatheter was attributed as the cause of cauda equina syndrome. This case report showed that, with the administration of high doses of hyperbaric anesthetics through the new catheter, poor distribution or risk of cauda equina syndrome were not observed.

Keywords: ANESTHETIC, Local: bupivacaine, lidocaine; ANESTHETIC TECHNIQUE, Regional: continuous spinal anesthesia; SURGERY, Abdominal: herniorrhaphy.

\section{INTRODUCTION}

Continuous spinal anesthesia has some advantages over spinal anesthesia with a single dose, being possible to titrate the level of analgesia and the extent of its duration according to the needs of the surgery or control of postoperative pain. In 1990, a 32G microcatheter was developed which was introduced through a $26 \mathrm{G}$ needle ${ }^{1}$. In 1991, it was suspected that the microcatheter could cause cauda equina syndrome after four cases were reported ${ }^{2}$, which led the FDA to issue an alert about its use.

In 1999, a new system for continuous spinal anesthesia to be used in anesthesia and control of postoperative pain ${ }^{4,5}$ as well as obstetric analgesia ${ }^{6}$ was described. It is composed of a $22 \mathrm{G}$ and $24 \mathrm{G}$ catheter over a $27 \mathrm{G}$ and $29 \mathrm{G}$ cut-bevel needle (Spinocath ${ }^{\top M}$ ) measuring $72 \mathrm{~cm}$ in length. The over-

Received from the Instituto de Anestesia Regional, Hospital São Bernardo, Rio de Janeiro.

1. Anesthesiologist

2. TCBC, FACS, General Surgeon

3. PhD, Assisting Professor of the Anesthesiology Department, Escola de Medicina de Botucatu, Universidade de São Paulo, Brazil

Submitted on February 9, 2010.

Approved on May 24, 2010.

Correspondence to:

Dr. Luiz Eduardo Imbelloni M.D.

Av. Epitácio Pessoa, 2356/203

Lagoa

22411-072 - Rio de Janeiro, RJ, Brazil

E-mail: dr.imbelloni@terra.com.br the-needle design eliminates leakage of cerebrospinal fluid (CSF) since the catheter seals immediately the dura-mater orifice. The intermediate-size catheter allows high flow, promoting easy homogenization of the anesthetic solution with the CSF, easy barbotage, and eliminated the potential risk of cauda equina syndrome.

The objective of this case report was to demonstrate the effectivity of continuous spinal anesthesia in a high risk patient undergoing a long duration surgery using high doses of local anesthetics.

\section{CASE REPORT}

This is a 78 years old male patient weighing $85 \mathrm{~kg}, 168$ $\mathrm{cm}$, and physical status ASA III. He was scheduled for surgery of bilateral inguinal and umbilical hernias. His medical history included hypertension, coronary artery disease, and chronic renal failure under conservative treatment. He had huge bilateral inguinal and umbilical hernias (Figures 1 and 2). He was being treated with aprozide (150/12.5 mg) for blood pressure control. Renal failure was being treated conservatively. He was hospitalized for one week for preoperative pneumoperitoneum by daily puncture and injection of air to stretch abdominal cavity and accommodate the huge herniated viscera.

After venoclysis with an $18 \mathrm{G}$ catheter, monitoring with a cardioscope, non-invasive blood pressure, and pulse oxi- 


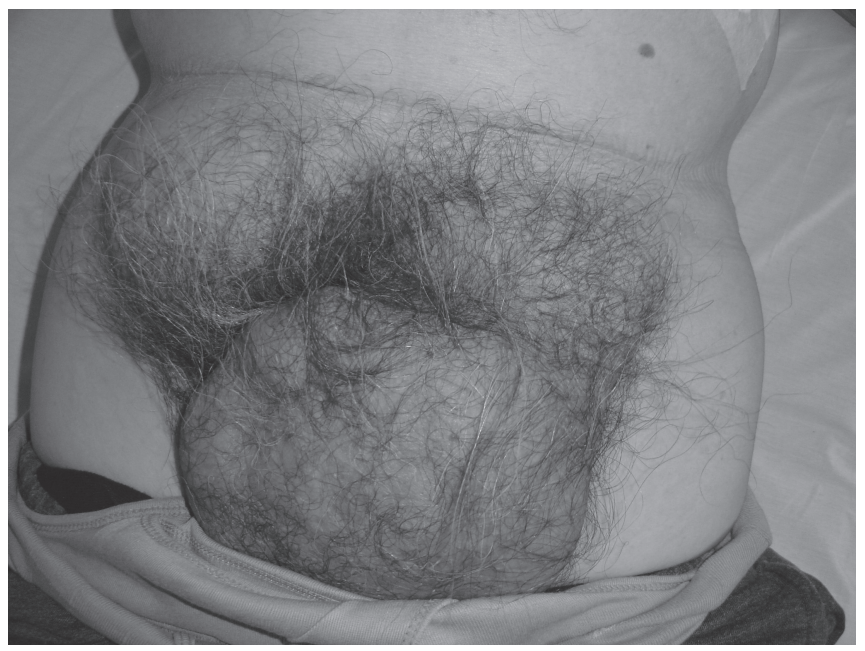

Figure 1. Picture of a Patient with inguinal hernias and umbilical hernia.

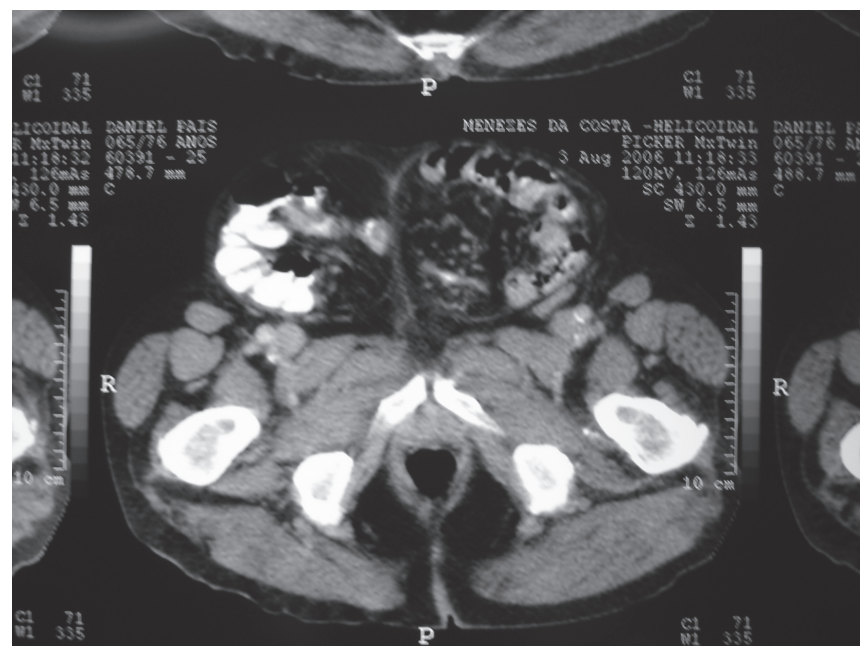

Figure 2. Magnetic Resonance Image of Hernias.

metry was instituted. The patient was sedated with $1 \mathrm{mg}$ of midazolam and $100 \mu \mathrm{g}$ of fentanyl, intravenously. With the patient on left lateral decubitus, after antisepsis with $70 \%$ alcohol and placement of a fenestrated field, the point demarcated as the $\mathrm{L}_{3}-\mathrm{L}_{4}$ space was infiltrated with $5 \mathrm{~mL}$ of $1 \%$ lidocaine. An 18G Crawford needle using the loss of resistance technique was used in the approach of the epidural space. A 22G catheter over a 27G needle (Spinocath $^{\mathrm{TM}}$, B. Braun - Melsungen) was introduced in the dura mater through the Crawford needle, perforating it after the introduction of only $20 \mathrm{~mm}$. Paresthesia was not observed and the reflow of CSF could be identified. The needle of the catheter was removed suing the retractor in the proximal tip of the system. Afterwards, the Crawford needle was removed. The luer connector was installed.

The catheter was fixed to the back of the patient. Four milliliters of isobaric $0.5 \%$ bupivacaine were mixed with $1 \mathrm{~mL}$ of hyperbaric $0.5 \%$ bupivacaine with $8 \%$ glucose, diluting the glucose to $1.6 \%$ and the same concentration of bupivacaine (Table I). The total volume of the solution was maintained in a $5 \mathrm{~mL}$ syringe. Fifteen milligrams $(3 \mathrm{~mL})$ of this solution were injected through the catheter. The remaining was used for further administration. After 10 minutes, the sensorial blockade reached the level of the $T_{11}$ dermatome and the motor blockade did not reach 3 in the modified Bromage scale. Upon incision for correction of the umbilical hernia, the patient complained of pain. Another $2 \mathrm{~mL}$ (10 mg) of the same solution were injected and the patient was placed on a head-down position of $30^{\circ}$, and we waited 10 minutes before restarting the surgery. The level of the blockade was still unsatisfactory. A new solution was prepared with $2 \%$ lidocaine with $1.6 \%$ glucose by adding $1 \mathrm{~mL}$ of the solution of hyperbaric lidocaine with $8 \%$ glucose to $4 \mathrm{~mL}$ of the isobaric $2 \%$ lidocaine solution. One milliliter $(20 \mathrm{mg})$ of this solution was then injected every 5 minutes, until the third dose, with the patient on a $30^{\circ}$ head-down position. After the third dose, the sensorial blockade reached enough level for surgery, which was restarted by repairing the umbilical hernia.

After correction of the umbilical hernia, the repair of the left inguinal hernia was initiated without complaints. After two hours and thirty minutes, the patient complained of pain and another $2 \mathrm{~mL}$ of the solution of lidocaine with $1.6 \%$ glucose were injected. A total of $25 \mathrm{mg}$ of $0.5 \%$ bupivacaine (hyperbaric, with $1.6 \%$ glucose) and $160 \mathrm{mg}$ of $2 \%$ lidocaine (hyperbaric, with $1.6 \%$ glucose) were used in the procedure, and the surgery lasted seven hours. Bradycardia and hypotension were not observed during the procedure.

At the end of the surgery, $100 \mu \mathrm{g}$ of morphine were injected through the catheter for control of postoperative pain. The catheter was removed at the end of the surgery and the patient was transferred to the Intensive Care Unit (ICU). Eight hours after placing the catheter, the patient complained of pain and was able to move the lower limbs. The patient was discharged from the ICU to the regular floor on the second postoperative day (PO), being discharged from the hospital on the $4^{\text {th }} \mathrm{PO}$ day. Phone follow-up on the $10^{\text {th }}, 20^{\text {th }}$, and $30^{\text {th }}$ days did not reveal any neurological complaints.

Table I - Evaluation of the Density of the Mixtures

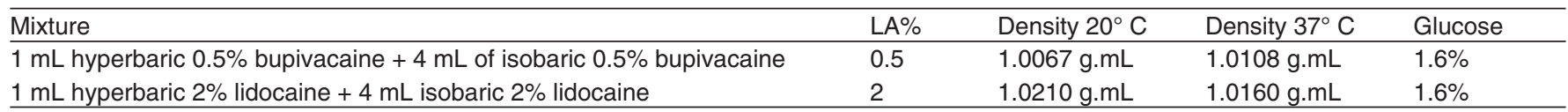




\section{DISCUSSION}

Better control of the level, intensity, and duration of anesthesia is the greatest advantage of continuous spinal anesthesia. By controlling the level of sensorial blockade, we can achieve better cardiocirculatory stability ${ }^{7}$ and the presence of the catheter guarantees the administration of further doses. In the present case, the catheter was fundamental for maintenance of the technique with excellent cardiocirculatory stability.

When continuous spinal anesthesia is used in orthopedics ${ }^{5}$ or obstetric analgesia ${ }^{6}$, the catheter-over-the needle is recommended. This catheter seals immediately the orifice in the dura-mater avoiding leakage of CSF through the puncture orifice. Since the set has a second orifice $5 \mathrm{~mm}$ from its tip, there is no need of introducing it more than $20 \mathrm{~mm}$ in the subarachnoid space. Preparations in cadavers for endoscopic studies demonstrated that all catheters introduced over $30 \mathrm{~mm}$ in the subarachnoid space developed loops ${ }^{8}$. When the catheter is removed, a loop could get entangled on a nerve root, causing direct trauma to the nerve by strangulation ${ }^{8}$. In the present case, the catheter was introduced no more than $20 \mathrm{~mm}$, enough for injections, without any problems upon its removal.

The cauda equina syndrome was correlated to the use of continuous spinal anesthesia with a microcatheter and high doses of local anesthetics ${ }^{2,9}$ leading to a reduction in the use of this technique. The poor distribution of the local anesthetic, which remained confined to the sacral region, was one of the mechanisms blamed for this syndrome ${ }^{9,10}$. Laboratorial analysis ${ }^{9}$ showed that the low speed of injection of the microcatheter attributed to its small diameter was responsible for the poor distribution of the local anesthetic, with accumulation of toxic concentration on the roots of the cauda equina. In the present study, an incomplete motor blockade and insufficient sensorial level was observed, but it was possible to complete the dose of bupivacaine, necessary for analgesia of the upper abdomen, and lidocaine to maintain analgesia of the lower abdomen to complete the procedure. The head-down position prevented sequestration of the solution at the dural cul-desac, therefore protecting the sacral roots.

The majority of the cases of post-spinal anesthesia cauda equina syndrome reported were in association with the administration of lidocaine and tetracaine 2,11 . The limited cephalad extension of the sensorial blockade, suggesting restricted distribution of lidocaine in the CSF probably resulted in a toxic effect of the local anesthetic ${ }^{2,9-11}$. It is believed that the toxic effect of the local anesthetic is seen especially in the cauda equina because the nerve roots that form the sacral roots are (a) longer (and more numerous for $S_{1}$ ) than their lumbar neighbors, (b) they do not have a protective sheath, and (c) due to their position in the subarachnoid space (especially $L_{5}, S_{1}$, and $S_{2}$ ), they are more exposed to the sacral sequestration of the local hyperbaric anesthetic ${ }^{12}$. In the present case, we chose bupivacaine. However, after the programmed dose of $25 \mathrm{mg}$ it was decided to switch to lidocaine, of shorter duration, which would benefit recovery in the last hours of surgery. By using the $22 \mathrm{G}$ set, poor distribution of either of the drugs was not observed resulting in fast recovery of the motor and sensorial blockade without transitory or definitive neurological complications.

The risk of transitory neurologic symptoms (TNS) was not eliminated by reducing the dose and concentration of lidocaine from $5 \%$ to $2 \%$, or even as low as $0.5 \%{ }^{13,14}$. Besides, not even the concentration of glucose ${ }^{15,16}$ or osmolarity of the local anesthetic solution ${ }^{16}$ affected the incidence of TNS. Animal and human studies have excluded glucose from any contribution to the nerve damage. Histological exams of the spinal cord of rats exposed to intrathecal glucose and neostigmine did not show nerve damage ${ }^{17}$. However, studies in diabetic rats raised the possibility that the altered glucose metabolism may contribute with the local anesthetic-induced nerve damage ${ }^{18}$. Glucose $7.5 \%$ with $5 \%$ lidocaine did not cause neurologic damage in rats, neither did it affect the compound action potential of unsheathed nerves in bullfrogs ${ }^{20}$. Several human studies relate glucose to the development of postspinal anesthesia TNS ${ }^{21}$. The majority of animal and human studies confirm the safety of the glucose administered in the subarachnoid space in concentrations of up to $7.5 \%$. In an experimental model in dogs, hyperbaric $5 \%$ lidocaine did not cause nerve damage when administered at a rate of 10 to 22 seconds. In another study with the same experimental model, in which hyperbaric $5 \%$ lidocaine was injected in the subarachnoid space over 60 seconds to reduce its diffusion in the CSF, $25 \%$ of the animals showed nerve damage ${ }^{23}$.

Poor distribution of the local anesthetic through the microcatheter has been recently implicated as a possible cause of cauda equina syndrome ${ }^{2,9-11}$. The administration of the hyperbaric local anesthetic through the Spinocath ${ }^{\mathrm{TM}}$ did not show poor distribution, without an elevated peak in the concentration of the anesthetic, and without the risk of developing cauda equina syndrome ${ }^{24}$. Since in the present case the patient had three large hernias, it was decided to reduce the baricity of the solution by changing the glucose concentration and maintaining the concentration of bupivacaine $(0.5 \%)$ and lidocaine $(2 \%)$.

Although experimental animal studies have provided evidence that some local anesthetics in clinical concentration could cause damage to the nerve tissue, the exact mechanism of the lesion is not clearly defined. Possible etiologic factors capable of triggering neurotoxicity (elevated doses e concentrations of the local anesthetic) are not the same that trigger TNS. Evaluation of the conduction of the nerve impulse shows that, in neurotoxicity, it is irreversible ${ }^{25}$ and it is normal in patients with TNS ${ }^{26}$. Despite the knowledge that all local anesthetics could be neurotoxic in experimental models, large scale investigations on the complications of spinal anesthesia demonstrate the safety of the local anesthetic for spinal anesthesia in men.

The use of two anesthetics was justified by the long duration of the surgery and, after the programmed dose of bupivacaine, lidocaine was the drug chosen to avoid possible residual motor blockade in high risk patients. Under the conditions of our patient, spinal anesthesia proved to be satisfactory for a large surgery of long duration, with excellent cardiocirculatory stability and without adverse events. 


\section{REFERÊNCIAS / REFERENCES}

01. Hurley RJ, Lambert DH - Continuous spinal anesthesia with a microcatheter technique. Preliminary experience. Anesth Analg, 1990;70:97-102.

02. Rigler ML, Drasner K, Crejcie TC et al. - Cauda equina síndrome after continuous spinal anesthesia. Anesth Analg, 1991;72:275-281.

03. Benson JS - FDA Safety alert. Cauda equina syndrome associated use of small-bore catheters in continuous spinal anesthesia. DANA J, 1992;60:223.

04. Imbelloni LE, Gouveia MA - Assessment of a new catheter for continuous spinal anesthesia. Rev Bras Anestesiol, 1999;49:315-319.

05. Imbelloni LE, Gouveia MA - Comparison between continuous spinal anesthesia with around-needle catheter and combined spinal-epidural anesthesia for orthopedic surgery. Rev Bras Anestesiol, 2000;50:419-424.

06. Imbelloni LE, Gouveia MA - Continuous spinal anesthesia with Spinocath $\circledast$ for obstetric analgesia. Int J Obstetric Anesth, 2006;15:171-172..

07. Labaille Th, Benhamou D, Westermann J - Hemodynamic effects of continuous spinal anesthesia: a comparative study between low and high doses of bupivacaine. Reg Anesth, 1992;17:193-196.

8. Ilias WK, Klimcha W, Skrbensky G et al. - Continuous microspinal anaesthesia: another perspective on mechanisms inducing cauda eqüina syndrome. Anaesthesia, 1998;53:618-623.

9. Rigler ML, Drasner K - Distribution of chateter injected local anesthetic in a model of the subarachnoid space. Anesthesiology, 1991;75:884-892.

10. Ross BK, Coda B, Heath $\mathrm{CH}$ - Local anesthetic distribution in a spinal model: A possible mechanism of neurologic injury after continuous spinal anesthesia. Reg Anesth, 1992;17:69-77.

11. Cheney FW, Domino KB, Caplan RA, Posner KL - Nerve injury associated with anesthesia: a closed claims analysis. Anesthesiology, 1999;90:1062-1069.

12. Hogan $Q$ - Anatomy of spinal anesthesia: some old and new findings. Reg Anesth Pain Med, 1998;23:340-343.

13. Hampl KF, Schneider MC, Pargger $\mathrm{H}$ et al. - A similar incidence of transient neurologic symptoms after spinal anesthesia with $2 \%$ and 5\% lidocaine. Anesth Analg, 1996;83:1051-1054.

14. Pollock JE, Liu SS, Neal JM et al. - Dilution of spinal lidocaine does not alter the incidence of transient neurologic symptoms. Anesthesiology, 1999;90:445-450.

15. Hampl KF, Schneider MC, Thorin D et al. - Hyperosmolarity does not contribute to transient radicular irritation after spinal anesthesia with hyperbaric 5\% lidocaine. Reg Anesth, 1995;20:363-368.

16. Pollock JE, Neal JM, Stephenson CA, et al. - Prospective study of the incidence of transient radicular irritation in patients undergoing spinal anesthesia. Anesthesiology, 1996;84:1361-1367.

17. Gurun MS, Leinbach R, Moore L et al. - Studies on the safety of glucose and paraben-containing neostigmine for intrathecal administration. Anesth Analg, 1997;85:317-323.

18. Kalichman MW, Calcutt NA - Local anesthetic-induced conduction block and nerve fiber injury in streptozotocin-diabetic rats. Anesthesiology, 1992;77:941-947.

19. Sakura S, Chan VWS, Ciriales R, Drasner K - The addition of $7.5 \%$ glucose does not alter the neurotoxicity of $5 \%$ lidocaine administered intrathecally in the rat. Anesthesiology, 1995;82:236-240.

20. Lambert L, Lambert D, Strichartz G - Irreversible conduction block in isolated nerve by high concentrations of local anesthetics. Anesthesiology, 1994;80:1082-1093.
21. Sakura S, Sumi M, Sakaguchi $Y$ et al. - The addition of phenylephrine contributes to the development of transient neurologic symptoms after spinal anesthesia with $0.5 \%$ tetracaine. Anesthesiology, 1997;87:771-778.

22. Pires SRO, Ganem EM, Marques M et al. - Effects of increasing spinal hyperbaric lidocaine concentrations on spinal cord and meninges. Experimental in dogs. Rev Bras Anestesiol, 2006;56:253-262.

23. Silva DM, Ganem EM, Marques M - Lidocaína hiperbárica a $5 \%$ administrada pela via subaracnóidea com agulha de Quincke em diferentes velocidades de injeção. Efeitos sobre a medula e meninges. Rev Bras Anestesiol, 2004;54:(Suppl):249A.

24. Holst D, Möllmann M, Scheuch E, Meissner K, Wendt M - Intrathecal local anesthetic distribution with the new spinocath catheter. Reg Anesth Pain Med, 1998;23:463-468.

25. Vianna PTG, Resende LA, Ganem EM et al. - Cauda equina syndrome after spinal tetracaine: electromyografic evaluation -20 years follow-up. Anesthesiology, 2001;95:1290-1291.

26. Pollock JE, Burkhead D, Neal JM et al. - Spinal nerve function in five volunteers experiencing transient neurologic symptoms after lidocaine subarachnoid anesthesia. Anesth Analg, 2000;90:658-665.

Resumen: Imbelloni LE, Gasparini Neto S, Ganem EM - Raquianestesia Continua con Altas Dosis de Anestésicos Locales.

Justificativa y objetivos: La mayor ventaja de la raquianestesia continua es el mejor control del nivel de intensidad y duración de la analgesia espinal. Con el advenimiento de los catéteres intermediarios (catéter por fuera de la aguja) y por su baja incidencia de cefalea y síntomas neurológicos, la técnica ha venido ganando credibilidad. El objetivo de este caso es relatar la posible seguridad del uso del nuevo catéter con una gran dosis de bupivacaína hiperbárica al $0,5 \%$ con glucosa al 1,6\% asociada a la lidocaína al $2 \%$ hiperbárica y con glucosa al $1,6 \%$.

Relato del caso: Paciente masculino, de 78 años, $85 \mathrm{~kg}, 168 \mathrm{~cm}$, estado físico ASA III, hipertenso, con coronariopatía e insuficiencia renal crónica. Candidato a cirugía de voluminosas hernias inguinales bilateral y umbilical, siendo sometido durante una semana a neumoperitoneo para crear espacio. Posteriormente a la venoclisis con catéter 18G, monitorización con cardioscopio, presión arterial no invasiva y oximetria de pulso, fue sedado con $1 \mathrm{mg}$ de midazolam y fentanil $100 \mu \mathrm{g}$ por vía venosa y colocado en decúbito lateral izquierdo. Sometido a la raquianestesia continua por vía mediana en $L_{3}-L_{4}$, y conjunto de aguja cortante $27 \mathrm{G}$ con catéter $22 \mathrm{G}$. La dosis total de anestésico utilizada en el procedimiento fue $25 \mathrm{mg}$ de bupivacaína al 0,5\% (hiperbárica con glucosa al 1,6\%) y 160 mg de lidocaína al $2 \%$ (hiperbárica con glucosa al 1,6\%) y morfina $(100 \mu \mathrm{g})$. Paciente con seguimiento hasta el $30^{\circ}$ día sin quejidos neurológicos.

Conclusiones: Recientemente, la mala distribución del anestésico local a través de microcatéter, se atribuyó a una causa del síndrome de cola de caballo. Este relato de caso mostró que, con la administración de altas dosis de anestésicos hiperbáricos a través del nuevo catéter, no hubo una mala distribución ni el riesgo de síndrome de cola de caballo. 